Industrial Health, 1978, 16, 73.

\title{
EFFECTS OF CADMIUM ON SOME ENZYME ACTIVITIES OF RAT LIVER-WITH SPECIAL REFERENCE TO DNA AND PROTEIN SYNTHESIS IN THE NUCLEI
}

\author{
Hiroko ONO, Tetsu ONO and Osamu WADA \\ Department of Hygiene, School of Medicine, Gunma University, \\ Maebashi, Gunma 371 Japna
}

(Received April 18, 1978)

\begin{abstract}
Male Wistar rats were injected intraperitoneally with cadmium acetate (20 $\mu$ moles/kg body weight) at two day intervals for six times. The increase of body weight was inhibited by the first injection of cadmium, but subsequent injections did not affect the further increase of body weight.

The weights of liver, kidney and spleen of the cadmium treated rats were not differed from control rats after six intraperitoneal injections. The contents of DNA and protein of livers were also not affected by the administration of cadmium.

The nuclear ${ }^{3} \mathrm{H}-\mathrm{dTTP}$ incorporating activity and the activity of glucose-6-phosphatase of livers were inhibited by the treatment of cadmium, while ${ }^{14} \mathrm{C}$-leucine incorporating activity of nuclei, acid phosphatase and monoamine oxidase were hardly affected.

It is suggested that cadmium inhibits the DNA polymerase activity directly or by affecting synthesis of the enzyme, or affects the initiation sites on DNA chains. It is also suggested that the enzymes participated in the nuclear incorporation of amino acids are fairly resistant to cadmium. These results might be of value to help explain the carcinogenic or teratogenic action of cadmium.
\end{abstract}

Cadmium is a relatively rare, physiologically non-essential and toxic element. Recently environmental pollutions due to the frequent employments in industry and hence the chances of human being exposed to cadmium increase substantially. In the meanwhile, biochemical and toxicological studies have shown that the absorbed cadmium tended to be retained for long periods, particularly in the liver and kidney ${ }^{1 \sim 3)}$. The discovery of a specific cadmium binding protein in these organs led to a great interest in cadmium toxicology and a very large literatures on this subject has appeared in the past few years ${ }^{4 \sim 7}$. However, the effect of cadmium on the nucleus of cells has received little attention.

The nucleus is known to be an organelle which contains almost all of the genetic information in the cell. Then, if cadmium affects on the mechanism concerning the expression of the genetic information in the nuclei, the influence may be formidable. In fact, developmental abnormalities of embryos have been reported to be induced by the 


\section{H. ONO, T. ONO AND O. WADA}

administration of cadmium to hamster ${ }^{8)}$, rat $^{9910)}$ or mouse ${ }^{11)}$. Sarcomas are also induced by cadmium at the injection sites ${ }^{12 \sim 15}$. Therefore, an elucidation of the effect of cadmium on the nucleic acid and protein synthesis may be potentially helpful in a basic understanding of the nature of cadminm toxicity in the whole animal.

In this investigation, enzyme activities in the nuclei concerning DNA synthesis and protein synthesis were measured in cadmium treated rats. The activities of acid phosphatase, a marker enzyme in lysosomal fraction, monoamine oxidase, a marker enzyme in outer membrane of mitochondria, and glucose-6-phosphatase, which distributes mainly in microsomal fraction were also assayed.

\section{Materials AND MethodS}

Male Wistar rats weighing $120 \mathrm{~g}$ were used. Cadmium acetate dissolved in $0.9 \%$ sodium chloride was injected intraperitoneally at a dose of $20 \mu \mathrm{moles} / \mathrm{kg}$ body weight at two day intervals for six times. One day after the last injection of cadmium, rats were killed by decapitation and livers were perfused in situ with cold saline via portal vein. The $10 \%$ liver homogenate in $0.25 \mathrm{M}$ sucrose- $3 \mathrm{mM} \mathrm{MgCl}_{2}$ was prepared in a teflonglass homogenizer. The homogenate was filtered through four layers of gauze, followed by centrifugation at $1,000 \mathrm{~g}$ for $10 \mathrm{~min}$. The pellet was suspended in $2.2 \mathrm{M}$ sucrose- 0.3 $\mathrm{mM} \mathrm{MgCl}$ and centrifuged at $54,000 \mathrm{~g}$ for $1 \mathrm{hr}$. The nuclear pellet at the bottom was washed with $0.25 \mathrm{M}$ sucrose- $3 \mathrm{mM} \mathrm{MgCl}_{2}$ and then finally resuspended in $0.25 \mathrm{M}$ sucrose- 3 $\mathrm{mM} \mathrm{MgCl} 2$ at a concentration of nuclei equivalent to $1 \mathrm{~g}$ tissue per $\mathrm{ml}$.

${ }^{3} \mathrm{H}$-dTTP incorporating activity of the nuclei was measured as described by Lynch et $\mathrm{al}^{16)}$. Reaction mixture contained $0.1 \mathrm{M}$ Tris- $\mathrm{HCl}$ buffer ( $\mathrm{pH} 7.4$ ), $4 \mathrm{mM} \mathrm{MgCl}_{2}, 8 \mathrm{mM}$ 2-mercaptoethanol, $2 \mathrm{mM}$ ATP, $0.08 \mathrm{mM} \mathrm{dCTP}$, dGTP and dATP, $2 \mu \mathrm{Ci}{ }^{3} \mathrm{H}-\mathrm{dTTP}(0.5$ $\mathrm{Ci} / \mathrm{mmole}$ ), and nuclear suspension equivalent to $200 \mu \mathrm{g}$ DNA in a final volume of 0.5 $\mathrm{ml}$. The incubation was carried out at $37^{\circ} \mathrm{C}$ for $20 \mathrm{~min}$. Reaction was stopped by adding ice cold $10 \%$ trichloroacetic acid and the acid-insoluble material was collected on glass fiber disc by filtration. The discs were washed with $5 \%$ trichloroacetic acid, ethanol and ether successibly. Dried discs were put into toluene-PPO-POPOP scintillator and counted in a liquid scintillation counter.

Amino acid incorporating activity of the nuclei was determined as described previously ${ }^{17)}$. The incubation mixure contained $0.2 \mathrm{M}$ sucrose, $1 \mathrm{mM} \mathrm{MgCl}_{2}, 40 \mathrm{mM} \mathrm{KCl}$, $20 \mathrm{mM}$ sodium phosphate buffer ( $\mathrm{pH} 6.0$ ), nuclei equivalent to $2-3 \mathrm{mg}$ protein and 0.5 $\mu \mathrm{Ci}$ of ${ }^{14} \mathrm{C}$-leucine $(305 \mu \mathrm{Ci} / \mathrm{mmole})$ in a final volume of $1.0 \mathrm{ml}$. The incubation was carried out at $37^{\circ} \mathrm{C}$ for $60 \mathrm{~min}$ and the reaction was terminated by adding cold $5 \%$ $\mathrm{HClO}_{4}-0.25 \% \mathrm{Na}_{2} \mathrm{WO}_{4}$. Acid insoluble precipitates were collected, washed with $10 \%$ $\mathrm{HClO}_{4}$ and then treated in $5 \% \mathrm{HClO}_{4}$ at $90^{\circ} \mathrm{C}$ for $15 \mathrm{~min}$. The pellet obtained by centrifugation was successibly washed with $10 \% \mathrm{HClO}_{4}$, ethanol, ethanol-ether $(3: 1, \mathrm{v} / \mathrm{v})$, and finally dissolved in $85 \%$ formic acid and aliquots were plated on stainless steel planchets. Radioactivity was determined by the use of a window-less gas flow counter. 


\section{CADMIUM AND ENZYME ACTIVITIES}

Another enzyme activities were determined as described below using liver homogenates. The activity of acid phosphatase was assayed by the procedure of DiPietro and Zengerle ${ }^{18)}$. Monoamine oxidase was assayed according to the procedure of McEwen, Jr. ${ }^{19)}$ Glucose-6-phosphatase activity was measured as described by Swanson ${ }^{20)}$.

Protein was assayed by the method of Lowry et al. ${ }^{21)}$ DNA was measured by the diphenylamine method ${ }^{22}$.

\section{RESUlTs}

The increase of body weights of the rats injected with cadmium acetate was stopped or rather decreased after the first injection, as shown in Fig. 1. The average body weight of the rats administered with cadmium was about $120 \mathrm{~g}$ (10 rats) at the second injection time, while that of control rats was $150 \mathrm{~g}$ (10 rats). However, the increase of body weights of cadmium treated rats was no longer affected by the subsequent injections of cadmium. After six times injections, the average body weight of the experimental group was $190 \mathrm{~g}$ and that of the control group was $210 \mathrm{~g}$.

Table 1 shows the wet weights of liver, kidney and spleen of the cadmium treated and control rats. No difference of the wet weight of these organs was observed between two groups.

The amount of DNA and protein per $g$ of liver was not changed after 6th injection

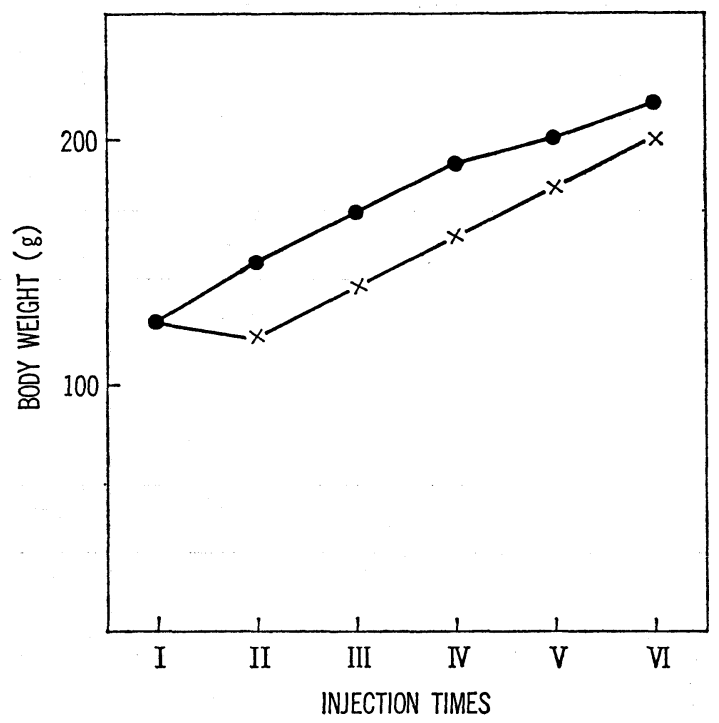

Fig. 1. Changes of body weight of rats administered with cadmium acetate. Cadmium acetate was injected intraperitoneally at a dose of $20 \mu \mathrm{moles} / \mathrm{kg}$ body weight at two day intervals. Control rats were injected with saline. - , control rats $(n=10)$, $\times-\times$, cadmium-injected rats $(n=10)$. 


\section{H. ONO, T. ONO AND O. WADA}

Table 1. Wet weights of liver, kidney and spleen of the rats treated with cadmium acetate as compared with those of the control rats.

\begin{tabular}{lccccc}
\hline & Rat No. & $\begin{array}{c}\text { Body weight } \\
(\mathrm{g})\end{array}$ & $\begin{array}{c}\text { Liver } \\
(\mathrm{g})\end{array}$ & $\begin{array}{c}\text { Kidney } \\
(\mathrm{g})\end{array}$ & $\begin{array}{c}\text { Spleen } \\
(\mathrm{g})\end{array}$ \\
\hline Control & 1 & 230 & 12.0 & 2.2 & 0.9 \\
& 2 & 180 & 8.3 & 1.7 & 0.7 \\
& 3 & 230 & 11.6 & 2.4 & 0.8 \\
& 4 & 210 & 10.6 & 2.0 & 0.8 \\
\cline { 2 - 6 } & mean \pm S.D. & $210 \pm 25$ & $10.6 \pm 2.9$ & $2.1 \pm 0.3$ & $0.8 \pm 0.1$ \\
\hline Cadmium-treated & 1 & 220 & 12.2 & 2.2 & 0.8 \\
& 2 & 180 & 9.5 & 1.9 & 1.0 \\
& 3 & 170 & 9.1 & 1.8 & 0.8 \\
& 4 & 220 & 11.4 & 2.0 & 0.9 \\
\cline { 2 - 6 } & mean \pm S.D. & $200 \pm 25$ & $10.6 \pm 1.5$ & $2.0 \pm 0.2$ & $0.9 \pm 0.1$ \\
\hline
\end{tabular}

Table 2. DNA and protein contents of livers of cadmium treated and control rats.

\begin{tabular}{|c|c|c|c|c|c|}
\hline \multirow[b]{3}{*}{ Control } & \multirow{3}{*}{$\begin{array}{c}\text { Rat No. } \\
1\end{array}$} & \multicolumn{3}{|c|}{ Whole liver } & \multirow{3}{*}{$\begin{array}{c}\text { Nuclei } \\
\text { Protein/DNA } \\
3.4\end{array}$} \\
\hline & & \multicolumn{2}{|c|}{$\begin{array}{l}\text { DNA Protein } \\
\text { (mg/g of liver) }\end{array}$} & \multirow{2}{*}{$\begin{array}{c}\text { Protein/DNA } \\
51\end{array}$} & \\
\hline & & 2.45 & 126.0 & & \\
\hline & 2 & 2.62 & 129.5 & 50 & 3.4 \\
\hline & 3 & 2.68 & 127.0 & 48 & 3.5 \\
\hline & 4 & 2.37 & 119.5 & 51 & 3.6 \\
\hline & mean \pm S.D. & $2.53 \pm 0.14$ & $125.5 \pm 4.3$ & 50 & 3.5 \\
\hline \multirow[t]{5}{*}{ Cadmium-treated } & 1 & 2.55 & 127.0 & 50 & 3.5 \\
\hline & 2 & 2.52 & 123.5 & 49 & 3.4 \\
\hline & 3 & 2.69 & 137.0 & 49 & 3.4 \\
\hline & 4 & 3.19 & 136.5 & 43 & 3.1 \\
\hline & mean \pm S.D. & $2.74 \pm 0.31$ & $129.8 \pm 6.9$ & 47 & 3.4 \\
\hline
\end{tabular}

of cadmium (Table 2). The ratio of protein to DNA in nuclei of the liver was also not affected by the injection of cadmium.

The enzyme activities in livers of the rats treated with cadmium acetate were compared with those of the control rats and the results were summarized in Table 3. The Table shows that: 1) ${ }^{3} \mathrm{H}$-dTTP incorporating activity of the nuclei obtained from livers of the rats treated with cadmium was reduced to about $60 \%(75-50 \%)$ of the control. 2) ${ }^{14} \mathrm{C}$-Leucine incorporating activity of the nuclei was not affected by the administration of cadmium. 3) The activity of acid phosphatase was not affected by the treatment 


\section{CADMIUM AND ENZYME ACTIVITIES}

Table 3. Enzyme activities of livers of cadmium-treated and control rats.

\begin{tabular}{|c|c|c|c|c|c|c|}
\hline & Rat No. & $\underset{\left.{ }^{3} \mathrm{H}-\mathrm{dTTP} \mathrm{T}^{\mathrm{a}}\right)}{\text { Incorporation }}$ & $\begin{array}{l}\text { of Incorporation of } \\
\left.{ }^{14} \mathrm{C} \text {-leucine }{ }^{b}\right)\end{array}$ & $\begin{array}{c}\text { Acid } \\
\text { phosphatase }\end{array}$ & $\begin{array}{c}\text { Amine } \\
\left.\text { oxidase }^{\mathrm{d}}\right)\end{array}$ & $\begin{array}{c}\text { Glucose-6- } \\
\left.\text { phosphatase }^{\ominus}\right)\end{array}$ \\
\hline \multirow[t]{5}{*}{ Control } & 1 & 2260 & 348 & 0.99 & 268 & 2.02 \\
\hline & 2 & 2260 & 272 & 1.05 & 272 & 1.98 \\
\hline & 3 & $-\dagger$ & 250 & 1.16 & 284 & 2.29 \\
\hline & 4 & 2280 & 329 & 1.40 & 240 & 1.87 \\
\hline & $\begin{array}{l}\text { mean } \\
\pm \text { S.D. }\end{array}$ & $\begin{array}{l}2270 \\
\pm 10\end{array}$ & $\begin{array}{r}300 \\
\pm 46\end{array}$ & $\begin{array}{r}1.15 \\
\pm 0.18\end{array}$ & $\begin{array}{r}266 \\
\pm 19\end{array}$ & $\begin{array}{r}2.06 \\
\pm 0.18\end{array}$ \\
\hline \multirow{5}{*}{$\begin{array}{c}\text { Cadmium- } \\
\text { treated }\end{array}$} & 1 & 1720 & 350 & 0.99 & 246 & 1.28 \\
\hline & 2 & 1070 & $-\dagger$ & 1.19 & 227 & 1.22 \\
\hline & 3 & 1600 & 294 & 0.97 & 230 & 1.11 \\
\hline & 4 & 1190 & 302 & 0.92 & 174 & 1.12 \\
\hline & $\begin{array}{c}\text { mean } \\
\pm \text { S.D. }\end{array}$ & $\begin{array}{r}1395 \\
\pm 310\end{array}$ & $\begin{array}{r}315 \\
\pm 30\end{array}$ & $\begin{array}{r}1.02 \\
\pm 0.12\end{array}$ & $\begin{array}{r}219 \\
\pm 31\end{array}$ & $\begin{array}{r}1.18 \\
\pm 0.08\end{array}$ \\
\hline
\end{tabular}

†Not determined.

a) $\mathrm{cpm} / \mathrm{mg}$ NDA

b) $\mathrm{cpm} / \mathrm{mg}$ protein

c) $\mu$ mole $\mathrm{p}$-nitrophenol liberated $/ \mathrm{min} / \mathrm{mg}$ protein

d) $\mathrm{m} \mu$ mole benzaldehyde liberated $/ 3 \mathrm{hr} / \mathrm{mg}$ protein

e) $\mu$ mole Pi liberated $/ 15 \mathrm{~min} / \mathrm{mg}$ protein

${ }^{3} \mathrm{H}$-dTTP and ${ }^{14} \mathrm{C}$-leucine incorporating activities were assayed using isolated nuclei. Another enzyme activities were_measured using homogenates.

with cadmium. 4) The activity of monoamine oxidase was slightly reduced by the cadmium injection. 5) The activity of glucose-6-phosphatase of the cadmium treated rats was reduced to about $60 \%$ of the control.

\section{Discussion}

It has been reported that cadmium binding protein, metallothionein, is induced in response to cadmium in the liver and kidney ${ }^{4 \sim 7)}$, and this protein is suggested to have a protective effect against cadmium toxicity ${ }^{232}{ }^{24)}$. Normal increase of body weight after second injection of cadmium may be related to the induction of cadmium binding protein.

After six intraperitoneal injection of cadmium, gross findings of livers were prominent. Anterior, median and posterior lobes could not be separated each other, and adhesion of liver to peritonealwall was striking. In spite of drastic morphological changes of the liver, the weight of the liver and contents of DNA and protein were not changed by the administration of cadmium.

Some discrepancies were observed in the effect of cadmium on the activity of enzymes in livers. Nuclear dTTP incorporating activity of livers of the cadmium treated rats 


\section{H. ONO, T. ONO AND O. WADA}

was reduced to approximately $60 \%$ of the control, while nuclear leucine incorporating activity was hardly affected by the administration of cadmium. In this respect, Stoll et al. reported that DNA synthesis in regenerating rat liver was markedly inhibited by a single intraperitoneal injection of cadmium ${ }^{25)}$. Our result on nuclear dTTP incorporating activity seems to be consisted with Stoll's observation. However, it should be pointed out that DNA polymerase present in the nuclei of non-proliferating tissues is reported not to increase significantlly during cell proliferation, and is suggested to function in non-replicative polymerization reactions such as DNA repair, while in proliferating tissues such as regenerating liver and hepatoma another DNA polymerase is present in the nuclei and is suggested to function as a replicating enzyme ${ }^{26 \sim 28)}$. Two possibilities are considered on the mechanism of the inhibiting effect of cadmium on the synthesis of DNA. One is that cadmium may interact with the DNA polymerase or inhibit the synthesis of the enzyme. Another is that cadmium may affect the initiation sites on DNA chains. The later possibility is based upon the ability of cadmium to alter the melting profile of liver $\mathrm{DNA}^{25)}$.

The nuclear leucine incorporating activity in livers of cadmium treated rats was not reduced in our experimental condition. Isolated nuclei are able to incorporate ${ }^{14} \mathrm{C}$-leucine into their proteins ${ }^{17}$. Biological meanings of the nuclear incorporation of amino acid in vitro are not yet clear, but in vitro and in vivo nuclear amino acid incorporating activities of regenerating livers have been reported to be increased in parallel after partial hepatectomy ${ }^{29130)}$. Addition of cadmium acetate at the concentration of $10 \mathrm{ppm}$ to the incubation mixture did not affect the incorporation of ${ }^{14} \mathrm{C}$--leucine into isolated nuclei (unpublished data). These results seem to indicate that the enzymes participating the nuclear incorporation of amino acid are fairly resistant to cadmium.

Cadmium was also shown to affect differently marker enzymes representing organelle in liver cells. Glucose-6-phosphatase activity, which distributes mainly in microsomal fraction was reduced to approximately $60 \%$ of the control. On the other hand, activity of acid phosphatase or monoamine oxidase, a marker enzyme in lysosomal or mitochondrial fraction respectively, was hardly affected by cadmium. The different effect of cadmium on the activity of enzymes may reflect the different distribution of cadmium in the cells. It may also be related to the nature or structure of enzyme. For instances, acid phosphatase contained in lysosome is resistant to $1 \mu \mathrm{M} p$-chloromercuribenzoate ${ }^{18)}$, a strong inhibitor of $\mathrm{SH}$ group. On the other hand, DNA polymerase from rat liver is markedly inhibited by another $\mathrm{SH}$-inhibitor substances, $0.5 \mathrm{mM} \mathrm{N}$-ethylmaleimide or 0.15 $\mathrm{mM} p$-hydroxymercuribenzoate ${ }^{31)}$.

It has been reported that cadmium either activates or inhibits a number of enzymes of liver. The activities of malic dehydrogenase ${ }^{32}$, histidine ammonia lyase ${ }^{33}$ and phosphorylase $^{34)}$ are among others enhanced by cadmium, while cytochrome oxidase ${ }^{34)}$, glutamic oxaloacetic transaminase ${ }^{35)}$ and $\delta$-aminolevulinic synthetase ${ }^{36)}$ are inhibited by cadmium. Accurate comparison, however, cannot be made because the conditions of experiments are different with each other. The dose, duration and route of administration of cadmium 


\section{CADMIUM AND ENZYME ACTIVITIES}

are not same in almost all the experiments.

Considering the present situation concerning the potential environmental impact of cadmium, it is felt that these biochemical investigations provide useful fundamental data which should be of value in regulating the hazard from cadmium exposure. Further, the actions of cadmium which have been demonstrated on nucleic acids and protein synthesis may be of significance to elucidate the mechanism of carcinogenic and teratogenic activities of cadmium.

\section{REFERENCES}

1) Gunn, S.A., Gould, T.C. and Anderson, W.A.D. (1968). J. Pathol. Bacteriol., 96, 87.

2) Stowe, H.D. and Wilson, M. (1972). Arch. Pathol., 94, 389.

3) Shaikh, Z.A. and Lucis, O.J. (1972). Arch. Environ. Health, 24, 410.

4) Piscator, M. (1964). Nord. Hyg. Tidskr., 45, 76.

5) Shaikh, Z.A. and Lucis, O.J. (1972). Arch. Environ. Health, 24, 419.

6) Nordberg, G.F., Nordberg, M. and Piscator, M. (1972). Biochem. J., 126, 491.

7) Weser, U., Rupp, H., Donay, F., Linneman, F., Voelter, W., Voetsch, W. and Jung, G. (1973). Eur. J. Biochem., 39, 127.

8) Holmbery, R.E. Jr. and Ferm, V.H. (1969). Arch. Environ. Health, 18, 873.

9) Barr, M. (1973). Teratology, 7, 237.

10) Chernoff, N. (1973). Teratology, 8, 29.

11) Ishizu, S., Minami, M., Suzuki, A., Yamada, M., Sato, M. and Yamamura, K. (1973). Ind. Health, 11, 127.

12) Heath, J.C., Daniel, M.R., Dingle, J.T. and Webb, M. (1962). Nature, 193, 592.

13) Kazantzis, G. (1963). Nature, 198, 1213.

14) Kazantzis, G. and Hanbury, W.J. (1966). Br. J. Cancer, 20, 190.

15) Gunn, S.A., Gould, T.C. and Anderson, W.A.D. (1967). Arch. Pathol., 83, 493.

16) Lynch, W.E., Brown, R.F., Umeda, T., Langreth, S.G. and Lieberman, I. (1970). J. Biol. Chem., 245, 3911.

17) Ono, H. and Terayama, H. (1968). Biochim. Biophys. Acta, 166, 175.

18) DiPietro, D.L. and Zengerle, F.S. (1967). J. Biol. Chem., 242, 3391.

19) McEwen, C.M. Jr. (1971). Methods in Enzvmology (Edited by Tabor, H. and Tabor, C.W.), Vol. 17B, p. 692. Academic Press, New York.

20) Swanson, M.A. (1955). Methods in Enzymology (Edited by Colowick, S.P. and Kaplan, N.O.), Vol. 2, p. 541. Academic Press, New York.

21) Lowry, O.H., Rosebrough, N.J., Farr, A.L. and Randall, R. (1951). J. Biol. Chem., 193, 265.

22) Dische, Z. and Schwarz, K. (1937). Mikrochim. Acta, $2,13$.

23) Nordberg, G.F. (1971). Environ. Physiol., 1, 171.

24) Suda, T., Horiuchi, N., Ogata, E., Ezawa, I., Otaki, N. and Kimura, M. (1974). FEBS Letters, 42, 23.

25) Stoll, R.E., White, J.F., Miya, T.S. and Bousquet, W.F. (1976). Toxicol. Appl. Pharmacol., 37,61 .

26) Lynch, W.E., Surrey, S. and Lieberman, I. (1975). J. Biol. Chem., 250, 8179.

27) Baril, E.F., Jenkins, M.D., Brown, O.E., Laszlo, J. and Morris, H.P. (1973). Cancer Res., 


\section{H. ONO, T. ONO AND O. WADA}

33, 1187.

28) Chang, L.M.S. and Bollum, F.J. (1972). J. Biol. Chem., 247, 7948.

29) Ono, H. and Takaku, F. (1972). J. Biochem., 72, 1567.

30) Umanã, R., Updike, S., Randall, J. and Dounce, A.L. (1964). The Nucleohistones (Edited by Bonner, J. and Ts'o, P.), p. 200. Holden-Day Inc., San Francisco.

31) Grisham, J.W., Kaufman, D.G. and Stenstrom, M.L. (1972). Biochem. Biophys. Res. Commun., 49, 420.

32) Weber, C.W. and Reid, B.L. (1969). Toxicol. Appl. Pharmacol., 14, 420.

33) Kato, A., Yoshioka, Y., Watanabe, M. and Suda, M. (1955). J. Biochem. 42, 305.

34) Sporn, A., Dinu, I. and Stoenescu, L. (1970). Rev. Roum. Biochim., 7, 299.

35) Sporn, A., Dinu, I., Stoenescu, L. and Cirstea, A. (1969). Nahrung, 13, 461.

36) Kench, J.E. and Gubb, P.J.D. (1970). Biochem. J., 120, 27 p. 